\title{
Urgensi Executeur Testamentair Dalam Pelaksanaan Wasiat
}

\author{
Putu Eva Laheri
}

ARA\&Co., E-mail: eva@aralawbali.com

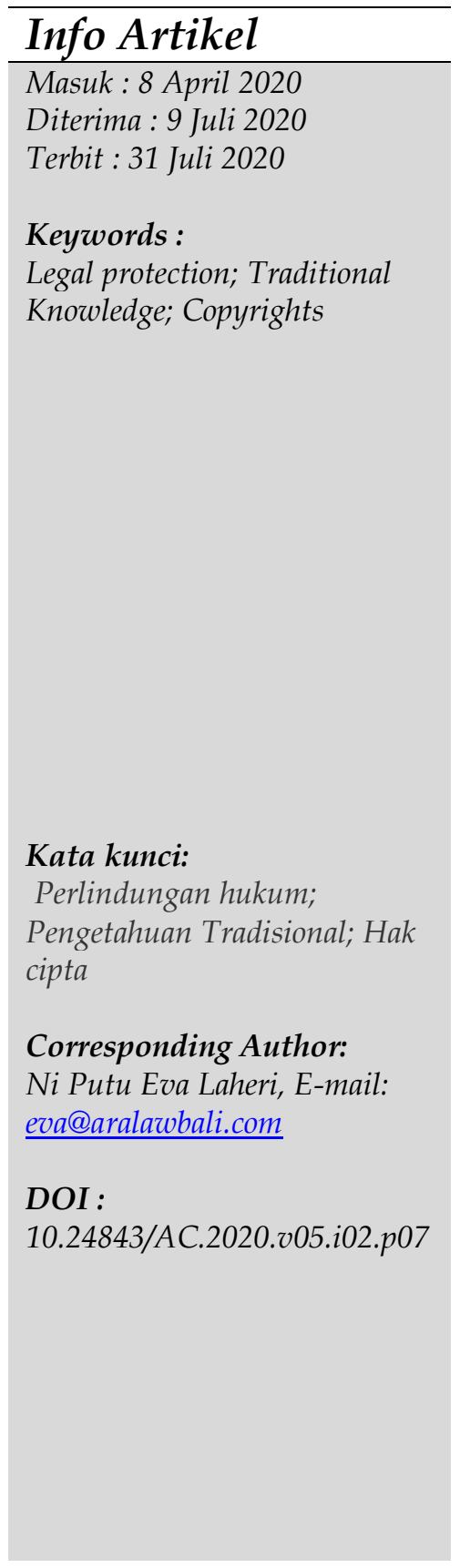

\begin{abstract}
Testament is a person's or testator's last will in associated with his assets. A testament is necessary to avoid disagreements among heirs regarding the distribution of inheritance assets even though a testament does not apply absolutely due to the heir has a legal rights to file a claim at court regarding the contents of the testament thus there is no absolute guarantee that the last wish of the testator shall be carried out, subject to the provisions of the testament made. The aims of this study are to examine the responsibilities and authority given to the will executor (execute testamentair) to secure the implementation of the testament after testator pass away. This article uses a method of normative research with the statutory approachment and concept approachment. The results show that the responsibility and authority of a will executor is regulated in the articles 1007 1014 of the Indonesian Code of Civil (KUHPerdata) including to secure the last testament of the deceased should be implemented, and in case there is a dispute, a will executore shall appear to court to confirm the legality of the will or testament of the testator.
\end{abstract}

\begin{tabular}{l} 
Abstrak \\
\hline Wasiat adalah amanat terakhir seseorang atau pewaris terkait \\
dengan harta kekayaannya. Wasiat bermanfaat untuk \\
menghindari selisih pendapat diantara ahli waris terkait \\
pembagian harta peninggalan pewaris meskipun pada \\
pelaksanaannya wasiat tidak berlaku absolut karena ahli waris \\
memiliki hak secara hukum untuk mengajukan gugatan ke \\
pengadilan berkaitan dengan isi wasiat sehingga tidak ada \\
jaminan mutlak keinginan terakhir dari pewasiat dapat \\
terlaksana sesuai dengan ketentuan wasiat yang dibuatnya. \\
Penelitian ini bertujuan untuk mengkaji pertanggungjawaban \\
dan wewenang yang diberikan kepada pelaksana wasiat \\
(executeur testamentair) untuk memastikan pelaksanaan wasiat \\
setelah pewaris atau pewasiat meninggal dunia. Penelitian ini \\
adalah penelitian hukum normatif menggunakan pendekatan \\
perundang-undangan dan pendekatan konseptual. Hasil \\
penelitian menunjukkan bahwa tanggung jawab dan wewenang \\
seorang pelaksana wasiat sesuai Pasal 1007 -1014 KUHPerdata) \\
diantaranya pelaksana wasiat wajib mengupayakan agar \\
kehendak terakhir pewaris dapat terlaksana dan apabila terjadi
\end{tabular}


perselisihan, pelaksana wasiat dapat mengajukan tuntutan ke pengadilan untuk mempertahankan berlakunya surat wasia sehingga peran pelaksana wasiat sangatlah penting untuk menjamin kepastian terlaksananya wasiat sebagai amanat terakhir dari seorang pewaris/pewasiat.

\section{Pendahuluan}

Wasiat merupakan amanat atau permintaan terakhir seseorang yang berkaitan dengan pembagian harta peninggalannya, dan harta waris atau harta peninggalan berarti harta pribadi pewasiat yang meninggal dunia setelah dikurangi utang-utang. ${ }^{1}$ Wasiat merupakan hal yang sangat pribadi dan rahasia karena secara hukum seseorang dibebaskan untuk membuat atau tidak membuat wasiat, ${ }^{2}$ namun dewasa ini banyak orang memilih membuat wasiat dengan berbagai tujuan dan manfaat diantaranya: untuk menghindari selisih pendapat diantara ahli waris terkait harta warisan atau agar para penerima waris mengetahui harta-harta apa saja yang ditinggalkan pewaris; guna memberikan harta atau aset ke pihak-pihak tertentu yang tidak termasuk ahli waris atau alasan lainnya.

Wasiat sebagaimana diatur dalam ketentuan Pasal 930 - Pasal 952 KUHPerdata yaitu wasiat yang dibuat dengan tangan sendiri (akta olografis) atau dengan bentuk akta umum dan akta rahasia, sangat memerlukan peran notaris dalam pembuatan, penyimpanan dan pendaftarannya ke pusat daftar wasiat berdasarkan ketentuan Pasal 16 ayat (1) huruf (j) UUJN-P. Oleh karena itu Notaris sebagai pilar penegak hukum ${ }^{3}$ wajib berperan aktif dalam membantu seseorang menyiapkan wasiat. Akan tetapi Notaris masih memiliki keterbatasan wewenang untuk menjamin kepastian terlaksananya wasiat, sehingga urgensi pembuatan wasiat tidak dapat diterapkan secara efektif meskipun isinya menyangkut kehendak terakhir dari seseorang atas harta kekayaan yang dimilikinya, diperoleh dengan usaha dan jerih payah si pewaris. Karakteristik wasiat yang bersifat rahasia dan pribadi merupakan alasan yang dapat menyebabkan permasalahan dalam pelaksanaan wasiat, seperti: ahli waris tidak mengetahui bahwa pewaris memiliki wasiat, sehingga selain Notaris dibutuhkan pihak lain yang diberikan peran atau kewenangan untuk dalam mengawal pelaksanaan wasiat, salah satunya yaitu Executeur Testamentair (Pelaksana Wasiat). Pengawalan pelaksanaan wasiat sangatlah penting guna memberikan kepastian hukum terhadap pewasiat yang memiliki kehendak terakhir atas harta kekayaannya. Akan sangat tidak adil bagi pewasiat apabila pewasiat telah bersusah payah memperoleh harta kekayaan dan mengeluarkan biaya yang tidak sedikit untuk menyiapkan wasiat akan tetapi kedepannya wasiat tersebut tidak dapat dieksekusi sebagaimana mestinya terlepas dari adanya permasalahan wasiat yang menyalahi ketentuan legitime portie.

\footnotetext{
${ }^{1}$ Salman, H.R.Otje. (2001). Hukum Waris Islam. Bandung: Refika Aditama, h. 15.

2 Asyhadie, H. Zaeni. (2018), Hukum Keperdataan dalam Perspektif Hukum Nasional KUH Perdata (BW), Hukum Islam dan Hukum Adat Jilid Kedua. Depok: RajaGrafindo Persada, h. 225.

3 Prabawa, B. (2017). Analisis Yuridis Tentang Hak Ingkar Notaris Dalam Hal Pemeriksaan Menurut Undang-Undang Jabatan Notaris Dan Kode Etik Notaris. Acta Comitas : Jurnal Hukum Kenotariatan, 2(1), 98-110. Doi:10.24843/Ac.2017.V02.I01.P09.
} 
Executeur testamentair adalah orang yang dipercaya untuk melaksanakan isi wasiat. Ketentuan Pasal 1005 KUHPerdata memberikan hak kepada pewaris guna mengangkat satu orang/lebih pelaksana surat wasiat langsung melalui wasiat atau akta bawah tangan menurut ketentuan Pasal 935 KUHPerdata ataupun akta notaris khusus. Selanjutnya Pasal 1011 KUHPerdata mengatur bahwa Executeur testamentair wajib mengupayakan agar keinginan pewaris bisa dilaksanakan dan ketika terjadi perselisihan, Executeur testamentair dapat mengajukan gugatan di pengadilan agar dapat mempertahankan berlakunya surat wasiat, maka berdasarkan ketentuan diatas dapat disimpulkan bahwa seorang Executeur testamentair memiliki kewenangan berdasarkan hukum untuk menjamin terlaksananya wasiat. Namun yang menjadi permasalahan adalah penunjukan Executeur testamentair tidak bersifat imperatif atau memaksa melainkan hanya sebatas hak yang diberikan kepada pewasiat untuk menunjuk atau tidak menunjuk Executeur testamentair. Disamping itu ketentuan Pasal 1021 KUHPerdata menegaskan bahwa tidak seorangpun diwajibkan untuk menerima tugas sebagai Executeur testamentair dan selain itu ketentuan Pasal 1015 KUHPerdata mengatur bahwa wewenang Executeur Testamentair tidak dapat dialihkan ke ahli waris dari Executeur testamentair. Peran Executeur testamentair yang sangat penting tampaknya dilemahkan berdasarkan ketentuan-ketentuan tersebut di atas.

Wasiat tidak mengenal asas yang mengharuskan adanya Executeur testamentair karena unsur wasiat hanya terdiri dari kecakapan, adanya pewasiat, ahli waris, harta warisan, pernyataan, saksi-saksi, batasan wasiat (legitime portie) dan kebatalan wasiat wasiat sehingga besar kemungkinan isi wasiat dibatalkan karena penerima wasiat baik masing-masing maupun secara bersama-sama memang tidak berkeinginan untuk itu ${ }^{4}$ atau karena keberadaan wasiat tidak diketahui oleh keluarga pewaris, permasalahan ini yang menyebabkan pembuatan wasiat tidak efektif dalam praktek hukum sampai saat ini. Dengan kata lain wasiat yang dibuat oleh pewasiat apabila tidak dilaksanakan menjadi tidak bermanfaat atau sia-sia. Permasalahan tersebut memotivasi Penulis untuk meneliti peran seorang Executeur testamentair dalam pelaksanaan wasiat dan akibat hukum jika pewasiat tidak menunjuk Executeur testamentair. Ketentuan Pasal 1007 KUHPerdata menegaskan bahwa Executeur testamentair adalah wakil pewaris/pewasiat yang diberikan tugas untuk menyelesaikan seluruh kehendak pewaris yang dituangkan dalam wasiat serta diberikan hak menguasai segala benda peninggalan atau atas sebagian tertentu saja ${ }^{5}$, agar kedepannya wasiat dapat digunakan sebagai instrument hukum untuk meminimalisir terjadinya sengketa pembagian waris karena penelitian-penelitian sebelumnya hanya membahas tentang konsekuensi hukum dari akta wasiat yang melanggar legitime portie oleh Muliana M., yang melakukan studi tentang konsekuensi yuridis pemberian wasiat yang melanggar legitime portie ${ }^{6}$, kedudukan wasiat atas warisan yang belum dibagikan oleh Sanjaya Umar Haris yang mengkaji tentang kemungkinan pembatalan wasiat melalui gugatan

\footnotetext{
4 Sanjaya, U. H. (2018). Kedudukan Surat Wasiat Terhadap Harta Warisan Yang Belum $\begin{array}{lllll}\text { Dibagikan Kepada Ahli Waris. Jurnal } & \text { 67-97. }\end{array}$ DOI: http://dx.doi.org/10.35586/.v5i1.317

5 Towidjojo, Riansyah. (2017). Kedudukan Pelaksana Wasiat atau Testament Berdasarkan Kitab Undang-Undang KUH Perdata. Jurnal Lex Crimen Vol. 6 No. 5 (2017), h. 28. https://ejournal.unsrat.ac.id/index.php/lexcrimen/article/view/16666/16183.

${ }^{6}$ Muliana, M., \& Khisni, A. (2017). Akibat Hukum Akta Hibah Wasiat Yang Melanggar Hak Mutlak Ahli Waris (Legitieme Portie). Jurnal Akta, 4(4), 739-744.
} 
di pengadilan7, kedudukan Executeur testamentair berdasarkan KUHPdt yang diteliti oleh R. Towidjojo mengkaji tentang kedudukan pelaksana wasiat dan berakhirnya tugas pelaksana wasiat $^{8}$, perlindungan hukum bagi ahli waris yang tidak mendapatkan warisan dikarenakan pewaris hanya memberikannya kepada salah satu ahli waris oleh Keren Yuni Santoso, dkk., yang menguraikan pembahasan tentang legitime portie dan Putusan Nomor: 69/PDT/2014/PTK yang dianggap bertentangan dengan legitime portie karena mengabulkan wasiat untuk ahli waris laki-laki saja9. Namun belum ditemukan artikel atau tulisan yang secara spesifik mengkaji tentang urgensi Executeur testamentair dalam pelaksanaan wasiat guna menjamin kepastian hukum pelaksanaan suatu wasiat.

\section{Metode Penelitian}

Penelitian dilakukan dalam bentuk penelitian hukum normatif karena membahas masalah kekosongan peraturan terkait dengan tidak adanya executeur testamentair dalam pelaksanaan wasiat. Maksud dari tidak adanya executeur testamentair (pelaksana wasiat) dalam penulisan ini adalah karena pewasiat sejak awal tidak menunjuk executeur testamentair (pelaksana wasiat atau penunjukan telah dilakukan namun executeur testamentair (pelaksana wasiat) meninggal bersamaan dengan pewasiat atau menolak penunjukkannya sebagai Pelaksana Wasiat. Adapun pendekatan yang digunakan berupa statute approach atau conseptual approach melalui teknik studi kepustakaan yang berasal dari bahan hukum primer yaitu peraturan perundang-undangan khususnya UUJN-P dan KUHPerdata; bahan hukum sekunder yaitu buku-buku yang membahas sumber bahan hukum primer, hukum kenotariatan, jurnal hukum, artikel hukum atau artikel lainnya; termasuk Kamus Besar Bahasa Indonesia dan/atau ensiklopedia sebagai bahan hukum tertier yang selanjutnya dianalisa dengan teknik analisis deskriptif guna menjawab konsep hukum yang dapat dipergunakan untuk mengkaji objek penelitian.

\section{Hasil Dan Pembahasan}

\subsection{Wewenang Pelaksana Wasiat (Executeur Testamentair)}

Wasiat adalah bagian dari hukum waris Indonesia dan wasiat harus memenuhi 3 (tiga) unsur pokok, yaitu: adanya Pewaris (erflater) atau orang yang meninggakan warisan; Ahli Waris (erfgenaam) atau si penerima warisan; dan Harta Warisan (nalaten schap) berupa semua harta yang ditinggalkan oleh pewaris setelah dikurangi seluruh utang-utang. ${ }^{10}$ Wasiat baru dapat dibuka atau dilaksanakan apabila pembuat wasiat (pewasiat) meninggal dunia. Adapun jenis-jenis wasiat berbeda-beda berdasarkan isi dan bentuknya. Wasiat berdasarkan isinya dibedakan menjadi wasiat pengangkatan waris (erfstelling) dan hibah wasiat (legaat), sedangkan wasiat berdasarkan bentuknya sesuai dengan ketentuan Pasal 931 KUHPerdata terbagi menjadi wasiat yang ditulis sendiri atau akta olografis, wasiat umum dan wasiat tertutup. ${ }^{11}$ Cara membuat dan

\footnotetext{
7 Sanjaya, U.H., Op.Cit.

8 Towidjojo, Riansyah., Op.Cit.

9 Santoso, K. Y., Ratna, P. S. W., Christanti, D. N., \& Fathoni, U. (2018). Perlindungan Hukum Bagi Ahli Waris Yang Tidak Mendapat Bagian Warisan Karena Ada Surat Wasiat Memberikan Warisan Kepada Salah Satu Ahli Waris. Jurnal Hukum Bisnis, 2(2), 115-127.

10 Moechtar, Oemar. (2019). Perkembangan Hukum Waris Praktik Penyelesaian Sengketa Kewarisan di Indonesia. Jakarta: Prenadamedia Group, h. 15.

11 Asyhadie, H. Zaeni, Op.Cit. h. 233.
} 
menyerahkan wasiat dapat dibedakan menjadi sebagai berikut: 1) Wasiat olografis dibuat dengan cara pewasiat menulis sendiri isi wasiat kemudian diserahkan kepada notaris agar disimpan dan disaksikan 2 (dua) saksi. Cara untuk menyerahkan wasiat tersebut kepada notaris ada dua yaitu dengan penyerahan secara terbuka yang kemudian oleh notaris dibuat akta notaris yang menjelaskan penyerahan wasiat dan selanjutnya ditandatangani pewasiat, saksi-saksi dan juga notaris, ataupun penyerahan dilakukan secara tertutup sehingga pewasiat harus menulis di sampul dokumen bahwa surat itu berisi wasiat dari pewasiat kemudian ditandatangani dihadapan notaris dan saksi-saksi; 2) Openbaar Testament dibuat oleh notaris dengan pewasiat menghadap kepada notaris serta menyampaikan kehendaknya dengan dihadiri 2 (dua) orang saksi; 3) Testament tertutup dibuat sendiri oleh pewasiat kemudian disegel dan penyerahannya wajib menghadirkan/disaksikan oleh 4 (empat) orang saksi. ${ }^{12}$

Pasal 875 KUHPerdata menyatakan surat testament merupakan akta yang berisikan pernyataan kehendak seseorang untuk dapat dikabulkan/terjadi, jika pembuat wasiat meninggal serta memungkinkan untuk dicabut kembali olehnya. Dengan demikian terdapat beberapa unsur dalam pembuatan wasiat berdasarkan Pasal 875 KUHPerdata, diantaranya: 1) Wasiat adalah akta sehingga wajib dibuat dalam tulisan baik berbentuk akta autentik atau di bawah tangan, yang isinya merupakan kehendak pewasiat. Namun Yahya Harahap memiliki pandangan berbeda karena menurutnya surat waris sudah semestinya dibuat dan/atau disimpan oleh notaris dalam bentuk akta notaris. ${ }^{13}$; 2) Isi wasiat merupakan pernyataan kehendak sehingga wasiat digolongkan sebagai tindakan hukum sepihak yang menimbulkan perikatan dan berakibat hukum yang tidak memerlukan kesepakatan atau konsensus dari ahli warisnya untuk menyatakan wasiat sah secara hukum; 3) wasiat baru berlaku atau terbuka setelah pewasiat meninggal dunia; dan 4) wasiat dapat dicabut kembali, artinya tidak semua kehendak dalam wasiat dapat dilaksanakan atau diperbolehkan dilaksanakan, ${ }^{14}$ seperti akta wasiat yang bertentangan dengan legitime portie dianggap dapat dibatalkan jika legitimaris menggugatnya. ${ }^{15}$ Ketentuan mengenai boleh tidaknya suatu wasiat untuk dicabut atau dibatalkan oleh ahli warisnya melalui gugatan apabila dianggap tidak memenuhi legitime portie merupakan dasar hukum yang dapat digunakan kapan saja untuk mengabaikan isi wasiat terlepas terbukti tidaknya di pengadilan. Maka penting adanya seseorang atau pihak yang diberikan kuasa oleh pewasiat untuk memastikan keinginan terakhirnya terlaksana.

Sebagaimana dikemukakan sebelumnya bahwa Hukum Waris di Indonesia mengenal adanya istilah atau peran Executeur testamentair dalam pelaksanaan wasiat berdasarkan Pasal 1005 - Pasal 1022 KUHPerdata. Dan Pasal 1007 KUHPdt sampai dengan Pasal 1014 KUHPdt mengatur perbuatan-perbuatan yang dapat dilakukan oleh seorang Executeur testamentair, diantaranya:

\footnotetext{
12 Perangin, Effendi. (2010). Hukum Waris. Jakarta: Rajawali Pers. h.80-81.

${ }^{13}$ Harahap, Yahya. (1993). Kedudukan, Kewenangan dan Acara Peradilan Agama. Jakarta: Pustaka Kartini. h. 167.

${ }^{14}$ Mu'arif, M. S. (2015). Perbandingan Wasiat dalam Perspektif Kompilasi Hukum Islam (KHI) dan Burgerlijk Wetboek (BW). Tafáqquh: Jurnal Penelitian Dan Kajian Keislaman, 3(2), 93-110

${ }^{15}$ Muliana, M., \& Khisni, A., Op.Cit.
} 
1. Executeur testamentair dapat menguasai sebagian atau seluruh barang peninggalan baik barang tetap atau barang bergerak untuk maksimal 1 (satu) tahun;

2. Executeur testamentair wajib mengupayakan penyegelan harta waris jika masih terdapat ahli waris yang dikategorikan belum cakap atau sedang berada dalam pengampuan atau bila ada ahli waris yang belum datang baik sendiri maupun menunjuk perantara;

3. Membuat rincian harta waris di depan ahli waris yang berada di Indonesia/seusai pemanggilan dengan sah;

4. Mengajutan tuntutan dan/atau menghadap pengadilan jika terjadi perselisihan terkait wasiat;

5. Executeur testamentair diberikan wewenang untuk mengusahakan penjualan atas barang bergerak dari peninggalan dan/atau satu atau beberapa barang tetap sesuai kebiasaan setempat dan di muka umum, dalam keadaan tidak tersedianya biaya hibah wasiat dengan persetujuan ahli waris;

6. Menguasai harta peninggalan;

7. Menangih seluruh piutang pewaris yang jatuh tempo selama jangka waktu penguasaan;

8. Executeur testamentair wajib memberikan rincian perhitungan serta pertanggungjawaban kepada siapapun yang memiliki kepentingan dengan cara memberikan barang serta efek secara keseluruhan sekaligus termasuk barang peninggalan serta penutup perhitunganyang menyebabkan dapat dilakukannya pembagian diantara ahli waris; dan

9. Membagi warisan jika dikehendaki oleh ahli waris.

Uraian mengenai perbuatan yang dapat dilakukan oleh Executeur testamentair tersebut di atas menunjukkan betapa pentingnya peran Executeur testamentair untuk memastikan terpenuhinya kehendak terakhir dari perwasiat dan apabila perbuatanperbuatan tersebut dikaitkan dengan teori otoritas atau wewenang menurut Max Weber maka perbuatan-perbuatan tersebut termasuk dalam otoritas atau wewenang rational. Max Weber mengemukakan ada 3 (tiga) golongan otoritas atau wewenang yaitu: 1) tipe rational (tipe formal atau legal) yaitu tipe otoritas berdasarkan keyakinan yang berasal dari sistem hukum yang diberlakukan pada masyarakat artinya suatu masyarakat tuntuk pada perintah atau pimpinan karena didasarkan oleh aturan legalitas formal. Ciri otoritas rational salah satunya yatu setiap hukum dapat ditetapkan secara formal dalam bentuk persetujuan atau atas kuasa (octrooi); 2) Otoritas tradisional yaitu wewenang yang sah erdasarkan pada aturan atau ketentuan tradisional murni tanpa mengenal wewenang berdasarkan aturan tetap. Otoritas tradisional tidak mengenal hierarki dan/atau mengangkatan yang teratur berdasarkan kontrak bebas serta kenaikan pangkat dan tidak ada pemberian gaji serta pendidikan yang digunakan sebagai norma; 3) Otoritas kharismatis yang didasarkan pada sifat luar biasa dari seseorang yang dipercaya memiliki kekuatan yang dianggap sesuatu 
yang luar biasa dan atas rasa kagum tersebut muncul pengakuan yang bersifat pribadi atas dasar dorongan perintah batin atau empati. ${ }^{16}$

Kewenangan Executeur testamentair sebagaimana diuraikan di atas merupakan kewenangan rational karena bersumber dari ketentuan formal dan berdasarkan kuasa yang diberikan oleh pewasiat kepada Executeur testamentair untuk melaksanakan wasiat berdasarkan kehendak terakhir dari pewasiat, dengan kata lain baik Executeur testamentair maupun kewenangannya telah diakui dan diberikan atau bersumber pada undang-undang yang dalam hal ini adalah KUHPerdata sehingga pihak-pihak yang terkait dalam proses pelaksanaan wasiat harus tunduk pada Executeur testamentair atas wewenang yang diberikan berdasarkan ketentuan Pasal 1007 KUHPdt sampai dengan Pasal 1014 KUHPdt. Perbuatan-perbuatan tersebut di atas selain sebagai bentuk wewenang yang diberikan secara hukum berdasarkan KUHPerdata (lex generalis), juga merupakan bentuk pelaksanaan tanggung jawab yang dibebankan oleh pewasiat kepada Executeur testamentair yang berarti jika terjadi kesalahan yang terjadi karena kelalaian ataupun kesengajaan dalam pemenuhannya maka Executeur testamentair harus bertanggungjawab secara hukum. ${ }^{17}$ Berdasarkan uraian dapat disimpulkan bahwa Executeur testamentair mempunyai peran yang penting dalam pelaksanaan wasiat.

Menurut John H. Langbein, ada beberapa hal yang dapat menghindari pihak ketiga menentang isi wasiat, salah satunya menunjuk saksi-saksi yang potensial untuk dapat membuktikan bahwa pewasiat sehat jasmani dan rohani sekaligus memiliki ingatan serta kesadaran yang baik ketika membuat wasiat guna menghindari klaim bahwa wasiat dibuat dalam keadaan tidak sadar dan/atau dibawah tekanan pihakpihak tertentu. Saksi- saksi tersebut bisa saja merupakan orang yang memiliki keahlian untuk membuktikan keadaan tersebut seperti seorang dokter atau psikolog atau bisa juga orang yang sangat familiar atau akrab dengan pewasiat ${ }^{18}$. Executeur testamentair dalam hal ini pun menurut Penulis dapat dijadikan saksi yang dapat membuktikan bahwa dalam pembuatan wasiat saat itu pewasiat dalam keadaan sehat jasmani dan rohani sehingga dalam pelaksanaan wasiat pun apabila ada pihak yang berkeberatan maka Executeur testamentair dapat mengajukan gugatan di pengadilan melawan pihak tersebut berdasarkan ketentuan Pasal 1011 KUHPerdata.

\subsection{Pelaksanaan Wasiat tanpa Pelaksana Wasiat (Executeur Testamentair)}

Executeur testamentair ditunjuk oleh pewasiat berdasarkan ketentuan Pasal 1005 KUHPerdata dan tugas Executeur testamentair berakhir karena Executeur testamentair telah menyelesaikan tugas yang diberikan, Executeur testamentair meninggal dunia, atau menjadi tidak cakap dalam melakukan tugasnya atau Executeur testamentair

\footnotetext{
${ }^{16}$ Marbun, S. F. (1996). Pemerintahan Berdasarkan Kekuasaan dan Otoritas. Jurnal Hukum IUS QUIA IUSTUM, 3(6), 28-43.

17 Meri, N. (2020). Tanggung Jawab Pelaksana Wasiat Dalam Menjalankan Wasiat Yang Dibuat Di Hadapan Notaris (Studi Kasus Perkara Nomor: 474/Pdt. G/2012/PN. Jkt. Sel) (Doctoral dissertation, Universitas Andalas), h.15.

${ }^{18}$ Langbein, J. H. (1994). Will contests, The Yale Law Journal Vol 103:2039, h. 2046, available at https://digitalcommons.law.yale.edu/cgi/viewcontent, accessed: 07 March 2020. 252Fscholar\%253Fhl\%253Den\%2526as_sdt\%253D0\%25252C5\%2526q\%253Dlaw\%252Bjournal \%252Bwill\%252Bexecutor\%2526btnG\%253D\#search=\%22law\%20journal\%20will\%20executor $\% 22$
} 
dihentikan dengan alasan abai terhadap tugasnya. Inti masalah dari penelitian ini adalah tentang bagaimana pelaksanaan wasiat apabila pewasiat tidak menunjuk Executeur testamentair, maupun apabila Executeur testamentair meninggal dunia dan/atau menolak penunjukan dirinya sebagai Executeur testamentair oleh pewasiat.

Ketentuan Pasal 1015 KUHPerdata menegaskan kekuasaan pelaksana suatu wasiat tidak dapat/secara langsung dialihkan kepada ahli warisnya dan ketentuan Pasal 1021 KUHPerdata menegaskan bahwa tidak seorangpun wajib menerima penugasan sebagai Executeur testamentair atau tugas mengelola warisan atapun hibah wasiat, namun bila bersedia menerima, wajib menyelesaikannya, pokok permasalahan Executeur testamentair muncul dari 2 (dua) ketentuan pasal tersebut di atas mengingat tidak ada satu ketentuan hukum pun yang memberikan kewenangan bagi pihak manapun termasuk pengadilan sekalipun untuk memerintahkan seseorang menjadi Executeur testamentair ataupun mengawasi pelaksanaan wasiat agar sesuai dengan kehendak pewasiat meskipun perselisihan rentan terjadi ketika eksekusi atau pelaksanaan wasiat dilakukan, sehingga yang menjadi pertanyaan apakah wasiat yang Executeur testamentairnya meninggal atau menolak penunjukkan sebagai pelaksana wasiat dapat tetap dieksekusi atau dilaksanakan.

Jika dipahami lebih jauh, ketentuan Pasal 1005 KUHPerdata pun tidak mewajibkan seorang pewasiat untuk menunjuk Pelaksana Wasiat atau dengan kata lain wasiat tetap bisa dijalankan ahli waris meskipun tidak ada Executeur testamentair 19 karena Executeur testamentair bukan unsur dalam wasiat, akan tetapi menelaah kewenangan yang dimiliki oleh seorang Executeur testamentair sebagaimana dinyatakan dalam ketentuan Pasal 1007 KUHPdt sampai dengan Pasal 1014 KUHPdt., maka Executeur testamentair memiliki peran penting dalam pelaksanaan wasiat. Mengutip teori perlindungan hukum yang dikemukakan oleh L. Rasjidi dan Ida Bagus Wyasa Putra yang dikenal sebagai teori perlindungan hukum prediktif dan antisipatif, maka Executeur testamentair adalah salah satu perwujudan dari perlindungan hukum yang diberikan kepada pewasiat agar kehendak terakhir terkait harta peninggalan pewasiat dapat terlaksana khususnya apabila ada pihak-pihak tertentu yang berusaha mengabaikan atau tidak menghormati isi wasiat sebagaimana kewenangan Executeur testamentair yang diberikan berdasarkan ketentuan Pasal 1011 KUHPdt. Executeur testamentair juga memberikan jaminan kepastian hukum atas tujuan pembuatan wasiat termasuk menjamin harta peninggalan pewasiat diberikan atau didistribusikan ke ahli waris yang berhak dan setelah itu wasiat baru dapat dikatakan memiliki manfaat secara hukum.

Wasiat adalah salah satu mekanisme perlindungan hukum yang memberikan kepastian kepada pewasiat bahwa harta peninggalannya akan dimanfaatkan atau diberikan kepada seseorang atau lebih ahli waris sesuai dengan kehendak pewasiat. Teori perlindungan hukum L Rasjidi dan Ida Bagus Wyasa P. meyakini bahwa suatu hukum tidak hanya berfungsi untuk menciptakan perlindungan adaptif dan fleksible

${ }^{19}$ Cahyaning Mustika Sari, I Gusti Ayu Putu Oka, Wairocana, I Gusti Ngurah dan Suyatna, I Nyoman. (2018). Peralihan Hak Atas Tanah Berdasarkan Hibah Wasiat Oleh Pelaksana Wasiat. Acta Comitas : Jurnal Hukum Kenotariatan, [S.1.], v. 3, n. 1, p. 157 - 170, apr. 2018. ISSN 2502-7573. Available at: <https://ojs.unud.ac.id/index.php/ActaComitas/article/view/39422>. Date accessed: 28 sep. 2019. doi: https://doi.org/10.24843/AC.2018.v03.i01.p12. 
saja melainkan juga harus bersifat prediktif dan antisipatif. ${ }^{20}$ Teori perlindungan hukum prediktif dan antisipatif memiliki pemahaman bahwa perlindungan hukum subjek hukum diberikan secara preventif maupun represif baik tertulis atau tidak, saat menegakkan peraturan hukum. ${ }^{21}$ Maka dari itu hukum harus memprediksi dan mengantisipasi kemungkinan-kemungkinan yang dapat menghambat terlaksananya isi wasiat atapun tidak terlaksananya isi wasiat karena suatu permasalahan hukum seperti ahli waris menolak isi wasiat atau tidak mengetahui adanya wasiat.

Minimnya pengawasan terhadap pelaksanaan wasiat selama ini mengakibatkan ketidakefektifan wasiat untuk menjamin kehendak terakhir dari pewasiat yaitu orang yang memiliki kehendak terakhir atas harta benda yang dimilikinya sebelum meninggal. Sangat tidak adil bagi pewasiat atau pewaris jika kehendaknya diabaikan begitu saja karena selalu ada alasan yang bersifat pribadi dan rahasia yang menjadi pertimbangan dari isi wasiat yang dibuatnya. Menurut Penulis, meskipun ketentuan penunjukan Executeur testamentair tidak berlaku secara imperatif, akan tetapi penting bagi Notaris untuk menggunakan kewenangannya berdasarkan ketentuan Pasal 15 ayat (2) huruf e UUJN-P berbentuk pemberian pengetahuan terkait peran Executeur testamentair pada saat pelaksanaan wasiat termasuk konsekunesi yuridis pelaksanaan wasiat tanpa Executeur testamentair karena Notaris tidak memiliki kewenangan untuk berperan aktif dalam memastikan terpenuhinya isi wasiat dari pewasiat khususnya apabila terjadi sengketa waris setelah pewasiat meninggal dunia.

\section{Penutup}

\subsection{Kesimpulan}

Executeur testamentair adalah seseorang atau lebih yang dapat ditunjuk dan diberikan kuasa oleh pewasiat untuk memastikan pelaksanaan isi wasiat. Kewenangan Executeur testamentair diatur dalam ketentuan Pasal 1007 KUHPdt sampai dengan Pasal 1014 KUHPdt, diantaranya kewenangan untuk mengajukan tuntutan dan/atau menghadap pengadilan jika terjadi perselisihan terkait wasiat. Akan tetapi pelaksanaan wasiat tetap dapat dilakukan oleh para ahli waris apabila pewasiat tidak menunjuk Executeur testamentair meskipun berpotensi sengketa dikemudian hari.

\subsection{Saran}

Meskipun wasiat tetap dapat dilaksanakan tanpa Executeur testamentair akan tetapi mengingat kewenangan yang dapat dilakukan oleh Executeur Testamentair untuk memastikan terlaksanakanya isi wasiat, maka penting bagi seseorang yang ingin membuat wasiat untuk menunjukan seorang maupun lebih Executeur testamentair agar memberikan jaminan dan kepastian hukum bahwa kehendak terakhir dari pewasiat dapat terpenuhi/terlaksana.

${ }^{20}$ Donandi, Sujana dan Etty Susilowati. (2015). Arti Penting Perjanjian Tertulis antara Pemilik dan Pengguna Karya Seni Fotografi untuk Kepentingan Promosi Komersial. Jurnal Law Reform Vol. 11 $\begin{array}{llllll}\text { No. } & 1 & \text { Tahun } & 2015 . & \text { h. } & 47 .\end{array}$ https://ejournal.undip.ac.id/index.php/lawreform/article/view/15753/11768.

${ }^{21}$ Sujayanthi, Masyuni Ni Wayan dan Agus Ngurah Arya Putraka. (2018). Perlindungan Hukum terhadap Alat Musik Tradisional Bali. Kalangwan Jurnal Seni Pertunjukan Vol. 4 No. 2 Desember 2018. h. 107. https://jurnal.isi-dps.ac.id/index.php/kalangwan/article/download/558/295/. 


\section{Daftar Pustaka}

\section{BUKU}

Asyhadie, H. Zaeni, 2018, Hukum Keperdataan dalam Perspektif Hukum Nasional KUH Perdata (BW), Hukum Islam dan Hukum Adat Jilid Kedua, RajaGrafindo Persada, Depok.

Harahap, Yahya, 1993, Kedudukan, Kewenangan dan Acara Peradilan Agama, Pustaka Kartini, Jakarta.

Moechtar, Oemar, 2019, Perkembangan Hukum Waris Praktik Penyelesaian Sengketa Kewarisan di Indonesia, Prenadamedia Group, Jakarta.

Perangin, Effendi, 2010, Hukum Waris, Rajawali Pers, Jakarta.

Salman, H.R.Otje, 2001, Hukum Waris Islam, Refika Aditama, Bandung.

\section{JURNAL}

Cahyaning Mustika Sari, I Gusti Ayu Putu Oka, Wairocana, I Gusti Ngurah dan Suyatna, I Nyoman, 2018, Peralihan Hak Atas Tanah Berdasarkan Hibah Wasiat Oleh Pelaksana Wasiat, Acta Comitas : Jurnal Hukum Kenotariatan, [S.1.], v. 3, n. 1, p. 157 - 170, apr. 2018. ISSN 2502-7573, Available at: <https://ojs.unud.ac.id/index.php/ActaComitas/article/view/39422>.

\begin{tabular}{llll}
\hline Date & accessed: & 28 & sep.
\end{tabular}

doi: https:// doi.org/10.24843/AC.2018.v03.i01.p12.

Donandi, Sujana dan Etty Susilowati, 2015), Arti Penting Perjanjian Tertulis antara Pemilik dan Pengguna Karya Seni Fotografi untuk Kepentingan Promosi Komersial, Jurnal Law Reform Vol. 11 No. 1 Tahun 2015, https://ejournal.undip.ac.id/index.php/lawreform/article/view/15753 /11768, diakses tanggal 28 September 2019.

Marbun, SF, 1996, Pemerintahan berdasarkan Kekuasaan dan Otoritas, Jurnal Hukum Vol. 3 No. 6 (1996).https://media.neliti.com/media/publications/84052ID-pemerintahan-berdasarkan-kekuasaan-dan-o.pdf, diakses tanggal 28 September 2019;

Mu'arif, Syamsul.Moh., 2015, Perbandingan Wasiat dalam Perspektif Kompilasi Hukum Islam (KHI) dan Burgerlijk Wetboek (BW), Jurnal Tafaqquh Vol. 3 No. 2 (2015), https://www.academia.edu/31386269/06._syamsul__PERBANDINGAN_WASIAT.pdf?auto=download, diakses tanggal 27 September 2019.

Muliana, Akhmad Khisni, 2017, Akibat Hukum Akta Wasiat yang Melanggar Hak Mutlak Ahli Waris (Legitime Portie), Jurnal Akta Vol. 4 No. 4 Desember 2017, http://jurnal.unissula.ac.id/index.php/akta/article/view/2520, diakses tanggal 26 September 2019.

Prabawa, B. (2017). Analisis Yuridis Tentang Hak Ingkar Notaris Dalam Hal Pemeriksaan Menurut Undang-Undang Jabatan Notaris Dan Kode Etik Notaris. Acta Comitas: Jurnal Hukum Kenotariatan, 2(1), 98-110. Doi:10.24843/Ac.2017.V02.I01.P09. 
Sanjaya, Umar Haris, 2018, Kedudukan Surat Wasiat terhadap Harta Warisan yang belum Dibagikan kepada Ahli Waris, Jurnal Yuridis Vol. 5, No. 1, Juni 2018: 67-97, DOI: 10.35586/v5i1.317 diakses tanggal 26 September 2019.

Santoso, K. Y., Ratna, P. S. W., Christanti, D. N., \& Fathoni, U. (2018). Perlindungan Hukum Bagi Ahli Waris Yang Tidak Mendapat Bagian Warisan Karena Ada Surat Wasiat Memberikan Warisan Kepada Salah Satu Ahli Waris. Jurnal Hukum Bisnis, 2(2), 115-127.

Sujayanthi, Masyuni Ni Wayan dan Agus Ngurah Arya Putraka, 2018, Perlindungan Hukum terhadap Alat Musik Tradisional Bali. Kalangwan Jurnal Seni Pertunjukan Vol. 4 No. 2 Desember 2018, https://jurnal.isidps.ac.id/index.php/kalangwan/article/download/558/295/, diakses tanggal 28 September 2019.

Towidjojo, Riansyah, 2017, Kedudukan Pelaksana Wasiat atau Testament Berdasarkan Kitab Undang-Undang KUH Perdata, Jurnal Lex Crimen Vol. 6 No. 5 (2017),

https://ejournal.unsrat.ac.id/index.php/lexcrimen/article/view/16666 /16183, diakses tanggal 26 September 2019.

\section{DISERTASI}

Meri, N. (2020). Tanggung Jawab Pelaksana Wasiat Dalam Menjalankan Wasiat Yang Dibuat Di Hadapan Notaris (Studi Kasus Perkara Nomor: 474/Pdt. G/2012/PN. Jkt. Sel) (Doctoral dissertation, Universitas Andalas), diakses tanggal 06 April 2020.

\section{PERATURAN PERUNDANG-UNDANGAN}

Kitab Undang - Undang Hukum Perdata

Undang-Undang Nomor 2 Tahun 2014 tentang Perubahan Undang-Undang Nomor 30 Tahun 2004 tentang Jabatan Notaris (Lembaran Negara Republik Indonesia Tahun 2014 Nomor 3) 